\title{
Acne fulminans in a patient with suspected bigorexia
}

\section{Trądzik piorunujący u pacjenta z podejrzeniem bigoreksji}

\author{
Agnieszka M. Czernecka', Aleksandra Batycka-Baran² \\ 'Department of Dermatology and Dermatological Oncology, Provincial Hospital, Opole, Poland \\ 2Department of Dermatology, Venereology and Allergology, Medical University, Wroclaw, Poland \\ 'Oddział Dermatologii i Onkologii Dermatologicznej, Szpital Wojewódzki, Opole, Polska \\ ${ }^{2}$ Katedra i Klinika Dermatologii, Wenerologii i Alergologii, Uniwersytet Medyczny, Wrocław, Polska
}

Dermatol Rev/Przegl Dermatol 2020, 107, 63-68

DOI: https://doi.org// 0.5 I | 4/dr.2020.93973

\author{
CORRESPONDING AUTHOR/ \\ ADRES DO KORESPONDENCJI: \\ Agnieszka M. Czernecka \\ Oddział Dermatologii \\ i Onkologii Dermatologicznej \\ Szpital Wojewódzki \\ ul. Katowicka 64 \\ 45-061 Opole \\ e-mail: ag.czernecka@gmail.com
}

\begin{abstract}
Introduction. Acne vulgaris is one of the most common skin diseases. Bodybuilding acne is the form of acne fulminans caused by use of anabolic agents to increase muscle mass. Bigorexia is a form of body dysmorphic disorder.

Objective. To present the case of a patient with suspected bigorexia which led to the development of acne fulminans.

Case report. A 21-year-old man was admitted to the Department of Dermatology with the diagnosis of acne fulminans and suspected bigorexia. Severe acne meaningfully diminished the Dermatology Life Quality Index and the psychophysical condition of the patient. Isotretinoin was introduced. The patient was given psychological and psychiatric advice.

Conclusions. The patient represents a psychodermatology domain case. A dermatologist is often the first physician a patient with body dysmorphic disorder symptoms visit. Cooperation between dermatologists and psychiatrists in treating the patient may be a key to therapeutic success.
\end{abstract}

\section{STRESZCZENIE}

Wprowadzenie. Trądzik pospolity jest jedną z najczęstszych chorób skóry. Bodybilding to postać trądziku piorunującego, spowodowana stosowaniem steroidów anabolicznych w celu zwiększenia masy mięśniowej. Bigoreksja stanowi odmianę dysmorfofobii.

Cel pracy. Przedstawienie przypadku pacjenta z podejrzeniem bigoreksji, która doprowadziła do wystąpienia trądziku piorunującego.

Opis przypadku. Mężczyzna 21-letni z podejrzeniem bigoreksji był hospitalizowany na oddziale dermatologii z powodu trądziku piorunującego. Nasilony trądzik znacznie obniżył wskaźnik jakości życia zależnej od dolegliwości skórnych (DLQI) i pogorszył stan psychofizyczny pacjenta. $\mathrm{W}$ terapii zastosowano izotretynoinę. Pacjent był konsultowany przez psychologa i psychiatrę.

Wnioski. Opisany przypadek należy do zakresu psychodermatologii. Dermatolog jest często pierwszym lekarzem, do którego zgłasza się pacjent z objawami dysmorfofobii. Kluczem do sukcesu terapeutycznego jest współpraca dermatologa, psychiatry i pacjenta.

Key words: acne vulgaris, body dysmorphia, anabolic agents.

Słowa kluczowe: trądzik pospolity, dysmorfofobia, steroidy anaboliczne. 


\section{INTRODUCTION}

Acne vulgaris is one of the most common skin diseases. It occurs in $80-100 \%$ of the population. This skin disorder significantly decreases patients' quality of life [1]. The pathogenesis of acne is highly complex. The main pathogenetic factors are connected to abnormal keratosis of hair follicle ostia, presence of the saprophytic bacterium Propionibacterium acnes and an incorrect response of the immune system of the skin. The excessive activity of sebaceous glands controlled by androgens - testosterone and dihydrotestosterone - is another key factor that contributes to the development of the disorder, which does not occur in eunuchs [2-5].

Acute febrile ulcerative acne (acne fulminans) is a form of concentrated acne, which tends to form numerous abscesses and significant scarring. It occurs mainly in young men. Accompanying symptoms may be fever, weight loss, muscle and joint pain (the result of bone marrow inflammation affecting the sternoclavicular joint) and/or erythema nodosum. In such cases, laboratory tests show elevated erythrocyte sedimentation rate erythrocyte sedimentation rate (ESR), leukocytosis, abnormalities in liver values and proteinuria $[4,6]$. Bodybuilding acne is a variant of acne fulminans caused by the use of hormonal products in order to increase muscle mass and improve fitness [6].

The word dysmorphobia (body dysmorphic disorder - BDD) is derived from the Greek word "dysmorphia", meaning ugliness, especially of the face. The term was introduced in 1886 by Morselli, who defined it as a subjective feeling of ugliness, which the patient considers to be a serious problem, while the patient's appearance is not abnormal or the changes in appearance are exaggerated by the patient. A common symptom of this disorder is frequent inspections of one's appearance, e.g. by looking into the mirror [7-12]. People suffering from BDD want to improve their appearance and are convinced that the problem lies in an actual defect rather than a subjective distorted perception of their body [9]. According to the ICD-10 classification, BDD is considered a mental disorder under code F45.2. The severity of symptoms may fluctuate from obsessive to delusional and back [7]. A person suffering from BDD may also be concerned with their body structure. About $80 \%$ of BDD patients have suicidal thoughts and as many as $15-28 \%$ attempt suicide $[7,9]$.

One variety of BDD is bigorexia (muscle dysmorphia) - often referred to as reverse anorexia or Adonis complex. The term was coined in 1997 and the first researcher to describe bigorexia was Harrison Pope. A patient suffering from bigorexia is obsessively pre-

\section{WPROWADZENIE}

Trądzik zwyczajny (acne vulgaris) jest jedną z najczęstszych chorób skóry, która występuje u 80-100\% populacji. Dermatoza ta znacząco obniża jakość życia pacjenta [1]. Patogeneza trądziku jest niezwykle złożona. Główne czynniki patogenetyczne są związane z nieprawidłowym rogowaceniem ujść mieszków włosowych, obecnością saprofitycznej bakterii Propionibacterium acnes oraz nieprawidłową reakcją układu immunologicznego skóry. Wzmożona aktywność gruczołów łojowych kontrolowanych przez androgeny - testosteron i dihydrotestosteron - jest także istotnym elementem rozwoju tej choroby, która nie występuje u eunuchów [2-5].

Trądzik piorunujący (acne fulminans) jest postacią trądziku skupionego z tendencją do tworzenia licznych ropni oraz znacznego bliznowacenia. Występuje głównie u młodych mężczyzn. Objawami towarzyszącymi mogą być: gorączka, utrata masy ciała, bóle stawowo-mięśniowe (wynik zapalenia szpiku kostnego z zajęciem stawu mostkowo-obojczykowego) i rumień guzowaty. $W$ badaniach laboratoryjnych $\mathrm{u}$ chorych często stwierdza się przyspieszone OB, leukocytozę, nieprawidłowości w zakresie wartości parametrów wątrobowych i białkomocz [4, 6]. Bodybuilding acne jest odmianą trądziku piorunującego spowodowaną stosowaniem preparatów hormonalnych w celu zwiększenia masy mięśniowej i poprawy kondycji [6].

Termin dysmorfofobia (body dysmorphic disorder BDD) pochodzi od greckiego słowa dysmorphia oznaczającego brzydotę, głównie twarzy. Wprowadził go w 1886 roku Morselli, który opisał dysmorfofobię jako subiektywne odczuwanie brzydoty, którą pacjent uważa za poważny problem, mimo że jego wygląd jest prawidłowy, lub wyolbrzymianie defektów wyglądu, zazwyczaj skórnych. Charakterystyczne dla osób z BDD jest bardzo częste ocenianie swojego wyglądu, np. poprzez przeglądanie się w lustrze [7-12]. Pragną one dokonać korekty swojej urody i są przekonane, że problemem jest rzeczywisty defekt, a nie zaburzona subiektywna percepcja ciała [9]. Dysmorfofobia jest zaliczana do zaburzeń psychicznych, według klasyfikacji ICD-10 F45.2. Natężenie objawów może się zmieniać od obsesyjnego do urojeniowego i odwrotnie [7]. Dysmorfofobia może także dotyczyć budowy ciała. U ok. $80 \%$ chorych na BDD występują myśli samobójcze, a aż 15-28\% z nich podejmuje próby samobójcze $[7,9]$.

Odmianą BDD jest bigoreksja (muscle dysmorphia), tzw. przeciwieństwo anoreksji (revers anorexia) lub kompleks Adonisa. Pojęcie to wprowadzono w 1997 roku. Pierwszym badaczem, który opisał bigoreksję, był Harrison Pope. Pacjent cierpiący na to schorzenie obsesyjnie myśli o rozbudowie masy mięśniowej 
occupied with building muscle mass and feels that their body will never be sufficiently muscled.

A person with muscle dysmorphobia spends a lot of time training their strength, repeatedly takes muscle measurements, follows various high-protein diets and/or even uses anabolic steroids. The patient is ashamed to expose their body (e.g. on a beach or at a pool) as it makes them feel embarrassed and dissatisfied. It is estimated that about $10 \%$ of gym customers suffer from bigorexia [7, 9, 13-15]. Being excessively preoccupied with one's body build leads to dysfunction in the patient's family as well as social and professional life [9].

When treating such patients, behavioural psychotherapy and pharmacotherapy are used. Sometimes it is necessary to also include antidepressants $[7,15]$.

\section{OBJECTIVE}

This article presents a psychodermatological case of a young man with suspected bigorexia that most likely led to the patient's use of anabolic drugs, consequently resulting in the development of acne fulminans in the patient.

\section{CASE REPORT}

A 21-year-old physical worker reported to the Department of Dermatology in Opole with suspected acne fulminans. Skin lesions had appeared about 2 months after the patient started to use anabolic agents in combination with intensive exercises at the gym in order to develop muscle mass. Initially, the patient had not agreed to be referred to a hospital, which he explained, among other things, by the need to continue taking hormones. Due to significant testosterone level abnormalities (exceeding the normal level by about a dozen-fold) and absence of results of tests necessary to undertake isotretinoin treatment, lymecycline at a dose of $2 \times 300 \mathrm{mg} /$ day was prescribed on an outpatient basis. Afterwards, the patient decided to undergo hospital treatment.

The patient was admitted in a good general condition. He reported severe pain in the area of skin lesions and bone and muscle pains, mainly of the shoulder band and weakness. The interview with the patient showed that during puberty, the patient exhibited acne lesions of mild intensity, which did not require therapy.

Physical examination revealed enlarged musculature, slight mobility restriction in the thoracic spine area and a minor forward inclination of the body and arms. Apart from that, no abnormalities were found. Skin lesions occurred in the facial, neck and torso areas - mainly in the upper and middle parts. There i uważa, że jego ciało nigdy nie będzie odpowiednio umięśnione. Spędza mnóstwo czasu na treningach siłowych, wciąż mierzy obwody mięśni, stosuje różne diety wysokobiałkowe, a nawet steroidy anaboliczne. Pacjent wstydzi się odsłaniać swoje ciało (plaża, basen), gdyż powoduje to jego zażenowanie i niezadowolenie. Szacuje się, że ok. 10\% klientów siłowni cierpi na bigoreksję [7, 9, 13-15]. Nadmierne zaabsorbowanie budową własnego ciała prowadzi do zaburzeń w życiu rodzinnym, społecznym i zawodowym [9].

W leczeniu pacjentów z bigoreksją, oprócz psychoterapii behawioralnej, stosuje się farmakoterapię. Czasami konieczne jest włączenie leków przeciwdepresyjnych $[7,15]$.

\section{CEL PRACY}

W pracy przedstawiono przypadek z dziedziny psychodermatologii dotyczący młodego mężczyzny z podejrzeniem bigoreksji, która prawdopodobnie przyczyniła się do stosowania przez niego leków anabolicznych, czego skutkiem był rozwój trądziku piorunującego.

\section{OPIS PRZYPADKU}

Mężczyzna, lat 21, pracownik fizyczny, zgłosił się na Oddział Dermatologii w Opolu z podejrzeniem trądziku piorunującego. Zmiany skórne pojawiły się ok. 2 miesięcy po rozpoczęciu stosowania przez pacjenta środków anabolicznych w połączeniu z intensywnymi ćwiczeniami na siłowni w celu rozbudowy masy mięśniowej. Mężczyzna początkowo nie wyraził zgody na skierowanie do szpitala, co motywował m.in. koniecznością dalszego przyjmowania hormonów. W związku ze znacznymi nieprawidłowościami stężenia testosteronu (kilkunastokrotne przekroczenie górnej granicy normy) i brakiem wyników badań niezbędnych do podjęcia terapii izotretynoiną zastosowano początkowo leczenie ambulatoryjne limecykliną w dawce $2 \times 300 \mathrm{mg} /$ dobę. Następnie pacjent zdecydował się na leczenie szpitalne.

Został przyjęty w stanie ogólnym dobrym, zgłaszał nasilone dolegliwości bólowe w okolicy zmian skórnych, bóle kostno-mięśniowe, głównie w obrębie obręczy barkowej, oraz osłabienie. W wywiadzie podawał występowanie od okresu dojrzewania zmian trądzikowych o lekkim nasileniu, niewymagających terapii.

W badaniu fizykalnym stwierdzono rozbudowaną muskulaturę, lekkie ograniczenie ruchowe w okolicy kręgosłupa piersiowego i minimalne pochylenie ramion oraz sylwetki do przodu. Poza tym nie wykazano odchyleń od normy. Stwierdzono bardzo liczne zmiany skórne w postaci zlewnych cyst 
were numerous lesions in the form of inflammatory cysts, pustules and inflammatory nodules with a tendency to form necrotic masses covered with haemorrhagic crusts (figs. 1, 2). During hospitalisation, additional tests were carried out; they showed elevated ESR of $35 \mathrm{~mm}$, leukocytosis over 16,000/UI in blood, a slightly elevated level of platelets $(353,000 / \mathrm{UI})$, elevated level of hormones, LH $9.9 \mathrm{mlU} / \mathrm{ml}$, SHGB $61 \mathrm{nmol} / 1$ and PSA $2.01 \mathrm{ng} / \mathrm{ml}$ (at discharge there was a rising tendency of $2.28 \mathrm{ng} / \mathrm{ml}$ ) and the presence of protein in urine $(352.5 \mathrm{mg} / \mathrm{l})$. Testosterone level was within normal limits, at $6.14 \mathrm{ng} / \mathrm{ml}$. X-rays of sternoclavicular joints did not reveal any irregularities. The patient consulted an endocrinologist, who recommended getting off hormonal drugs. The psychologist assessed the patient as follows: "The patient is fully conscious, his allo - and autopsychic orientation is correct. The emotional state of the patient is normal. He admits that he devotes all his time to exercising at the gym. He took anabolic agents because he no longer had the strength to exercise and did not see any results in his body. The patient does not see anything wrong with using these drugs. He does not intend to give them up and he claims that in a few years' time, he will start to take them again". In addition, the DLQI questionnaire was evaluated with a score of 15 points. In the clinic, the patient was prescribed isotretinoin treatment at a dose of $60 \mathrm{mg} /$ day and prednisone at a dose of $30 \mathrm{mg} /$ day. Due to

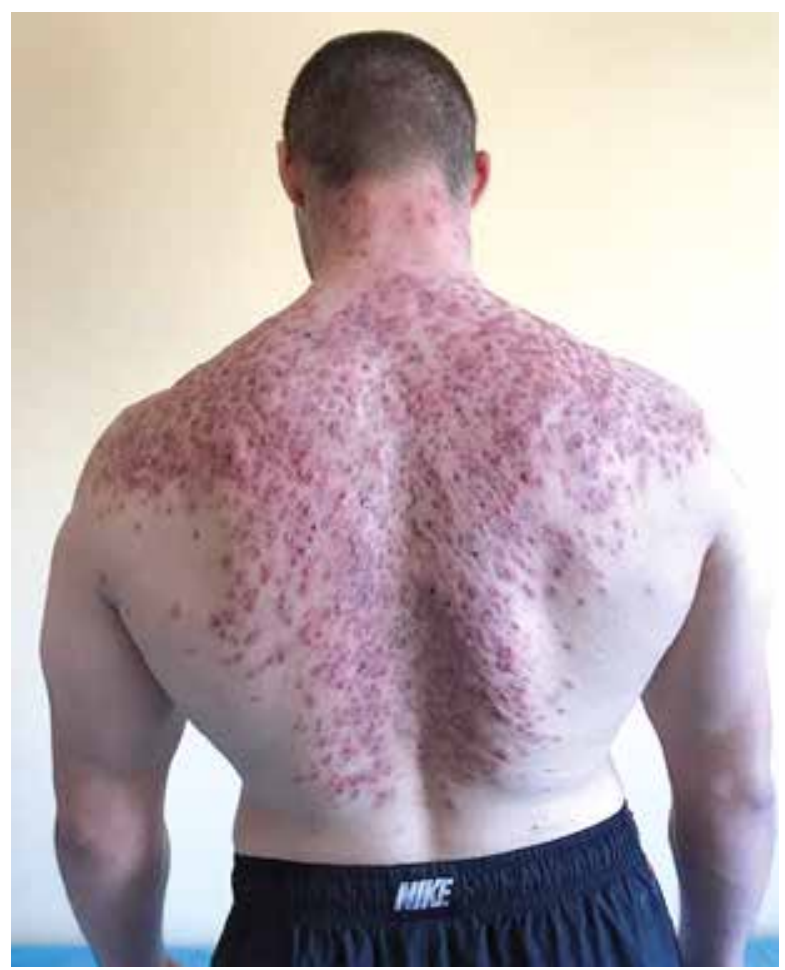

Figure I. Athletic body silhouette

Rycina I. Atletyczna sylwetka zapalnych, krost oraz guzów zapalnych z tendencją do tworzenia mas martwiczych pokrytych krwotocznymi strupami (ryc. 1, 2). Podczas hospitalizacji przeprowadzono badania dodatkowe, które wykazały przyspieszone OB - $35 \mathrm{~mm}$, leukocytozę - ponad 16 tys./Ul, nieco podwyższony poziom płytek 353 tys./Ul, podwyższone stężenie hormonów: LH - 9,9 mlU/ml, SHGB - $61 \mathrm{nmol} / 1$ i PSA - 2,01 ng/ $\mathrm{ml}$ (przy wypisie tendencja do narastania: 2,28 ng/ $\mathrm{ml}$ ) oraz obecność białka w moczu (352,5 mg/1). Stężenie testosteronu mieściło się w granicach normy - 6,14 ng/ml. Badanie rentgenograficzne stawów mostkowo-obojczykowych wykazało stan prawidłowy. Pacjent był konsultowany przez endokrynologa, który zakazał mu przyjmowania leków hormonalnych, oraz przez psychologa, który napisał w konsultacji: „Pacjent w kontakcie logicznym, orientacja alo- i autopsychiczna prawidłowa. Pacjent w nastroju prawidłowym, przyznaje, że cały swój czas wolny poświęca na ćwiczenia na siłowni. Pobierał odpowiednie anaboliki, ponieważ już nie miał siły wykonywać ćwiczeń i nie widział ich rezultatów. Pacjent nie widzi nic złego w zażywaniu tych preparatów, nie ma zamiaru z nich rezygnować, jak twierdzi - za kilka lat do nich wróci". Ponadto zastosowano skalę DLQI - wynik 15 pkt. U pacjenta włączono izotretynoinę $\mathrm{w}$ dawce $60 \mathrm{mg} /$ dobę i prednizon $\mathrm{w}$ dawce $30 \mathrm{mg} /$ dobę. $Z$ powodu dolegliwości bólowych mężczyzna otrzymywał ketoprofen p.o. w dawce $100 \mathrm{mg} /$ dobę. Uzyskano częściową poprawę stanu klinicznego. Pacjent został wypisany do domu w stanie ogólnym dobrym. Zalecono ambulatoryjną konsultację urologiczną (w USG stwierdzono przerost gruczołu krokowego) oraz psychiatryczną. Na konsultację psychiatryczną pacjent zgłosił się 6 miesięcy od rozpoczęcia terapii dermatologicznej, w zdecydowanie lepszym stanie klinicznym niż przy przyjęciu do szpitala. Psychia-

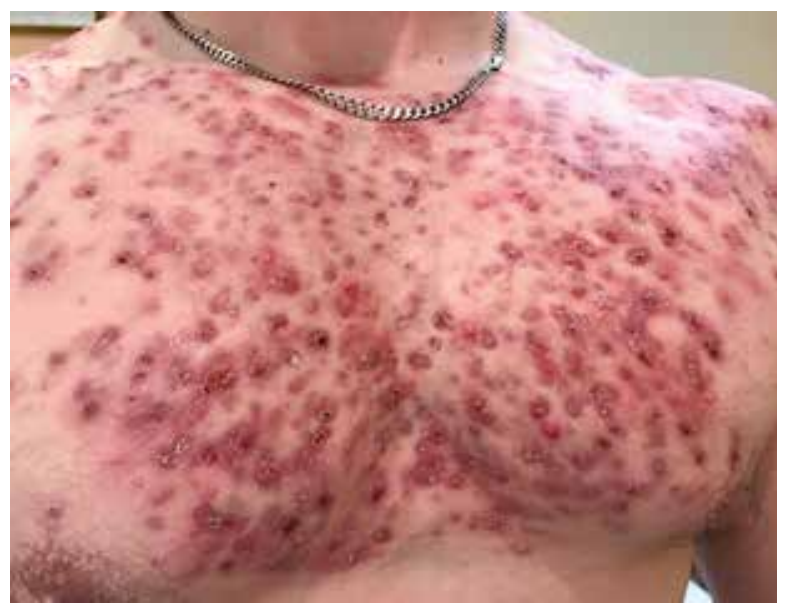

Figure 2. Acne fulminans

Rycina 2. Trądzik piorunujący 
pain the patient was prescribed ketoprofen p.o. at a dose of $100 \mathrm{mg} /$ day. Partial improvement in clinical condition was achieved. The patient was discharged in good general condition. Outpatient visit to an urologist was recommended due to prostate hypertrophy revealed in the ultrasound and psychiatric consultations were advised. The patient received psychiatric consultation 6 months after the beginning of the dermatological treatment in a significantly better clinical condition compared to his state upon admission to the hospital. The psychiatrist stated that it is difficult to make a clear diagnosis of bigorexia after a single visit, although the interview does indicate the abovementioned diagnosis. The doctor recommended further monitoring and observation of the patient; however, the patient did not show up at the following planned appointments.

\section{DISCUSSION}

The patient described above is a complex case from the field of psychodermatology, a discipline that deals with the relationship between psychiatric, psychological and dermatological symptomatology. Estimates indicate that up to $60 \%$ of patients with skin diseases have various disorders: depressive, anxious and other [7].

Body dysmorphic disorder in the form of bigorexia, i.e. continuous lack of acceptance of the structure of one's body, induced the patient to take anabolic drugs. The consequence was acne fulminans. Skin disfigurement put an additional burden on the patient physically (intensified purulent skin lesions with scarring), emotionally and psychologically (further decrease in self-acceptance, isolation, feeling of helplessness - the patient's quality of life was lowered in virtually all its aspects), including avoiding social interactions and intimate contacts $[7,9]$. The dysmorphic disorder of the patient shifted towards acne, which became a leading problem involving stigmatisation. His acne problem started to absorb the patient more than bigorexia. It is highly worrisome that the patient intends to take anabolics again in the future and that he is not concerned about the consequences of this decision.

Body dysmorphic disorder is a disorder which is relatively common in dermatology and psychiatry, yet it is underdiagnosed. The psychological consequences of BDD in the form of embarrassment and anxiety may influence the social and professional life of the people who suffer from it.

The data show that $8-14 \%$ of dermatological patients suffer from BDD. Among the patients of plastic (aesthetic) surgeons, this percentage reaches up to $53 \%$, while the prevalence rate in the general population is about $0.7-2.4 \%$ [16].

Introduction of a BDD questionnaire onto the Polish market, through the validation of an appropriate scale, may improve the rates of properly diagnosed BDD. tra stwierdził, że po jednorazowym zbadaniu pacjenta trudno jednoznacznie ustalić rozpoznanie bigoreksji, choć wywiad wskazuje na taką diagnozę. Zalecił dalsze monitorowanie i obserwacje pacjenta, który jednak nie pojawił się na kolejnych planowych wizytach.

\section{OMÓWIENIE}

Opisano złożony przypadek z zakresu psychodermatologii - dyscypliny, która zajmuje się związkami symptomatologii psychiatryczno-psychologicznej z dermatologiczną. Według danych szacunkowych nawet u ok. $60 \%$ pacjentów z chorobami skóry występują rozmaite zaburzenia depresyjne, lękowe i inne [7].

Dysmorfofobia w postaci bigoreksji, czyli ciągłego braku akceptacji budowy własnego ciała, skłoniła pacjenta do stosowania leków anabolicznych. W konsekwencji doprowadziło to do wystąpienia trądziku piorunującego. Oszpecenie skóry bardzo obciążyło pacjenta zarówno pod względem fizycznym (ropne zmiany skórne z bliznowaceniem), jak i emocjonalno-psychicznym - jeszcze większy brak samoakceptacji, izolacja, poczucie bezsilności. Nastąpiło obniżenie jakości życia w zasadzie we wszystkich jego aspektach, w tym unikanie kontaktów towarzyskich i intymnych [7, 9]. Zaburzenia dysmorficzne przesunęły się w kierunku trądziku, który stał się dla pacjenta głównym problemem w związku ze stygmatyzacją. Aktualnie trądzik absorbował pacjenta bardziej niż bigoreksja. Bardzo niepokojący jest fakt, że pacjent zamierzał za jakiś czas powrócić do przyjmowania leków anabolicznych i nie przejmował się konsekwencjami.

Dysmorfofobia jest stosunkowo częstym problemem w dermatologii i psychiatrii, lecz niedostatecznie rozpoznawanym. Psychologiczne konsekwencje BDD w postaci zakłopotania lub niepokoju moga wpływać na życie społeczne i zawodowe osób dotkniętych tym zaburzeniem.

Dane wskazują, że u 8-14\% pacjentów dermatologicznych obecna jest BDD. W gabinetach chirurgii plastycznej (estetycznej) odsetek ten wzrasta nawet do $53 \%$, przy wskaźniku rozpowszechnienia w populacji 0,7-2,4\% [16].

Wprowadzenie na rynek polski kwestionariusza BDD, poprzez walidację odpowiedniej skali, może poprawić rozpoznawalność tej choroby.

Podsumowując - dermatolog jest często pierwszym lekarzem, do którego zgłasza się pacjent z objawami BDD. Zasadne jest diagnozowanie pod tym kątem, jak również ocena ewentualnych zaburzeń lękowych i depresyjnych. Ważne jest szkolenie dermatologów w zakresie psychodermatologii oraz ścisła współpraca z psychiatrami. 
To sum up, the dermatologist is often the first doctor whom a patient with BDD symptoms visits. It is advisable to screen dermatological patients for BDD, anxiety and depression disorders.

\section{CONCLUSIONS}

The key to the therapeutic success of the patient described above is the close cooperation of the dermatologist, psychiatrist and the patient, whose attitude towards the problem of taking androgens is not rational. It is also important to draw the attention of teachers, gym owners and the general media to the problem of bigorexia and the harmfulness of anabolic use. An unnaturally muscular body in men should not be promoted.

\section{WNIOSKI}

Kluczem do sukcesu terapeutycznego w opisanym powyżej przypadku jest ścisła współpraca dermatologa, psychiatry i pacjenta, który podchodzi do problemu przyjmowania androgenów w sposób nieracjonalny. Należy zwrócić uwagę nauczycieli, właścicieli siłowni oraz szeroko pojętych mediów na problem bigoreksji i szkodliwości stosowania leków anabolicznych. Nie należy propagować nienaturalnie umięśnionej sylwetki u mężczyzn.

\section{KONFLIKT INTERESÓW}

Autorzy nie zgłaszają konfliktu interesów.

\section{CONFLICT OF INTEREST}

The authors declare no conflict of interest.

\section{References}

\section{Piśmiennictwo}

1. Szepietowski J., Kapińska-Mrowiecka M., Kaszuba A., Langner A., Placek W., Wolska H., et al.: Acne vulgaris: pathogenesis and treatment. Consensus of the Polish Dermatological Society. Przegl Dermatol 2012, 99, 649-673.

2. du Viver A.: Atlas dermatologii klinicznej. S. Majewski (ed. Polish edition). Urban \& Partner, Wrocław, 2002.

3. Cohen B.A.: Dermatologia dziecięca. B. Lecewicz-Toruń (ed. Polish edition). Wyd. Czelej, Lublin, 2009.

4. Szybejko-Machaj G.: Choroby gruczołów potowych i łojowych. [In:] Dermatologia pediatryczna. M. Miklaszewska, F. Wąsik (eds.). Volumen, Wrocław, 2000, 113-119.

5. Jamin C.: Acne in women: a manifestation of hyperandrogenizm. Medical Staff Dermatologie 2016, 93, 14-18.

6. Braun-Falco O., Plewig G., Wolff H.H., Burgdorf W.H.C: Dermatologia. W. Gliński, H. Wolska, P. Zaborowski (eds. Polish edition). Wyd. Czelej, Lublin, 2004.

7. Szepietowski J., Pacan P., Reich A., Grzesiak M.: Psychodermatologia. Uniwersytet Medyczny im. Piastów Śląskich we Wrocławiu, Wrocław, 2015.

8. Szepietowski J., Pacan P.: Dysmorfofobia - opis przypadku. Dermatol Estet 2003, 24, 42-44.

9. Dudek D., Rymaszweska J.: Psychiatria pod krawatem. Medical Education, Warszawa, 2016.

10. Wright P., Stern J., Phelan M.: Sedno psychiatria. J. Rybakowski, F. Rybakowski (eds. Polish edition). Elsevier Urban \& Partner, Wrocław, 2005.

11. Pużyński S.: Leksykon psychiatrii. Państwowy Zakład Wydawnictw Lekarskich, Warszawa 1993, 119.

12. Pacan P., Szepietowski J.: Dysmorfofobia i trichotilomania: najczęstsze psychodermatozy w dermatologii estetycznej. Ars Medica Aethetica 2006, 3, 58-60.

13. Phillips K.A., Siniscalchi J.M.: Depression, anxiety, anger and somatic symptoms in patients with BDD. Psychiatr Q 2004, 75, 309-320.

14. Michalska A., Szejko N., Jakubczyk A., Wojnar M.: Nonspecific heating disorders - a subjective review. Psychiatr Pol 2016, 50, 502-503.

15. Leone J.E., Sedory E.J., Gray K.A.: Recognition and treatment of muscle dysmorphia and realated body image disorders. J. Athl Train 2005, 40, 352-359.

16. Ritter V., Fluhr J.W., Schliemann-Willers S., Elsner P., StrauB B., Stangier U.: Zaburzenia dysmorficzne ciała, adaptacja społeczna i motywacja wśród ambulatoryjnych pacjentów dermatologicznych. Dermatol Kosmetol 2015, 44, 73-79.

Received: 30.05 .2019

Accepted: 19.10 .2019

Otrzymano: $30.05 .2019 \mathrm{r}$.

Zaakceptowano: $19.10 .2019 \mathrm{r}$.

How to cite this article

Czernecka A.M., Batycka-Baran A.: Acne fulminans in a patient with suspected bigorexia. Dermatol Rev/Przegl Dermatol 2020, 107, 63-68. DOI: https://doi.org/10.5114/dr.2020.93973. 